Halaman 12-20

\title{
Penerapan Model Pembelajaran Problem Based Learning dengan Memanfaatkan Potensi Lokal untuk Meningkatkan Aspek Problem Solving pada Higher-Order Thinking Skills
}

\author{
Implementation of Problem Based Learning Model by Using Local Potention \\ to Increase Problem Solving Aspect in Higher Order Thinking Skills \\ Dhora Vasminingtya ${ }^{a}$, Sajidan ${ }^{b}$, Umi Fatmawati $^{c}$ \\ ${ }^{a}$ Pendidikan Biologi FKIP UNS, Email: dhora.vasminingtya@gmail.com \\ ${ }^{\mathrm{b}}$ Pendidikan Biologi FKIP UNS, Email: adjids2002@yahoo.com \\ c Pendidikan Biologi FKIP UNS, Email: umifatmawati@yahoo.com
}

Diterima 25 Agustus 2014, disetujui 25 September 2014

\begin{abstract}
This research's aim is to increase the problem solving skill of the students in X-A of SMA Negeri Sragen Billingual Boarding School Gemolong academic Year 2013/2014. The matter is about Enviroment Pollution through Problem Based Learning application by using local area potention. This research is a class action research which consists of three cycles. Each cycle contains of planning, implementing, observing and reflecting. The research subject is the students in X-A of SMA Negeri Sragen Billingual Boarding School Gemolong academic Year 2013/2014. Data of research were obtained by test and non test technique. Data validation were used triangulation of methods and triangulation of observers. The obtained data were analyzed using descriptive technique.The results of this research showed that according triangulation the average percentage for IDEAL problem solver. IDEAL problem solver design measured with performance assement consist of IDEAL process and IDEAL product. The average of IDEAL problem solver become value of problem solving skill for every student. The result of the research shows that the implementation of problem based learning increase the students' problem solving skill that covers the IDEAL problem solver. The total average of IDEAL problem solver in the X-A class SBBS increased from 42,0 move up into 85,7 score. This research's conclusion is the implementation of problem based learning can increase the problem solving skill of the students in of SMA Negeri Sragen Billingual Boarding School Gemolong academic Year 2013/2014 about enviroment pollution material.
\end{abstract}

Key Words: Problem based learning, problem solving skill

\section{Pendahuluan}

Hasil belajar yang paling tinggi menurut Gagne dalam Ibrahim (2012) adalah keterampilan penyelesaian masalah. Oleh karena itu setiap pembelajaran sebaiknya diorientasikan untuk melatih keterampilan penyelesaian masalah siswa.

$\begin{array}{rcr}\text { Wena } & (2009) & \text { memandang } \\ \text { penyelesaian } & \text { masalah } & \text { sebagai suatu }\end{array}$

proses untuk menemukan kombinasi dari sejumlah aturan yang dapat diterapkan dalam upaya mengatasi situasi yang baru. Menurutnya, penyelesaian masalah merupakan proses untuk mendapatkan seperangkat aturan pada tingkat yang lebih tinggi. Apabila seseorang telah mendapatkan suatu kombinasi perangkat aturan yang terbukti dapat dioperasikan sesuai dengan situasi yang sedang dihadapi maka ia tidak saja dapat 
menyelesaikan suatu masalah, melainkan juga telah berhasil menemukan sesuatu yang baru yaitu perangkat prosedur atau strategi yang memungkinkan seseorang dapat meningkatkan kemandirian dalam berpikir (Gagne, 1985).

Hasil survey PISA tahun 2009 menjelaskan bahwa Indonesia pada bidang kajian sains berada pada peringkat ke-60 dari 65 negara berdasarkan informasi yang diperoleh dari laman situs Kementerian Pendidikan dan Kebudayaan Republik Indonesia (http://litbang.kemdikbud.go.id). Predikat tersebut mencerminkan bagaimana mutu pendidikan di Indonesia selama ini. Rendahnya mutu pendidikan di Indonesia ini, diperkirakan karena guru di sekolah masih belum menerapkan solving dan keahlian menganalisis terhadap suatu pelajaran pada siswa. Padahal Wena (2009) menjelaskan bahwa pada dasarnya tujuan akhir pembelajaran adalah menghasilkan siswa yang memiliki pengetahuan dan keterampilan dalam menyelesaikan masalah yang dihadapi kelak di masyarakat. Jadi keterampilan penyele-saian masalah sangat penting artinya bagi siswa dan masa depanya.

Berdasarkan hasil observasi mengenai kemampuan Problem Solving di kelas XA SBBS yang diukur dengan indikator IDEAL Problem solver yang terdiri dari 48 untuk nilai IDEAL proses dan 36 untuk IDEAL produk. Sehingga didapatkan rerata kelas yaitu 42 untuk nilai IDEAL Problem Solving. Dari rerata tersebut dapat diketahui bahwa kemampuan Problem Solving siswa masih rendah. Sehingga perlu adanya perbaikan pembelajaran untuk meningkatkan kemampuan Problem Solving. Kemampuan Problem Solving siswa dapat dilatih jika menggunakan metode dan model pembelajaran yang tepat.

Terkait dengan model pembelajaran, salah satu model yang dapat melibatkan peran aktif siswa untuk bekerjasama dalam rangka memaksimalkan kondisi belajar adalah pembelajaran berdasarkan berbasis masalah atau PBL. Pembelajaran ini merupakan salah satu pembelajaran inovatif yang menggunakan masalah sebagai titik awal memulai membahas sesuatu yang baru dalam pembelajaran (Ibrahim, 2005). PBL diawali penyajian suatu masalah pada siswa yang kemudian dilakukan penyelidikan untuk memperoleh penyelesaian masalah tersebut sehingga secara tidak langsung siswa dapat dilatih keterampilan penyelesaian masalah. Masalah yang diselesaikan PBL merupakan masalah yang otentik yang nyata dan sering ditemui sehari-hari.

Pencemaran lingkungan adalah kajian yang paling sering ditemui dalam 
kehidupan sehari-hari karena kehidupan manusia tidak lepas dari lingkungan sekitarnya. Pencemaran lingkungan membahas tentang penyebab dan sumber-sumber pencemaran serta usaha manusia dalam mengatasi pencemaran yang terjadi. Tema ini cocok dengan model PBL karena siswa sering menjumpai masalah lingkungan dan dituntut untukmengatasi permasalahanya.

Proses pembelajaran yang dilakukan siswa dalam Problem based Learning dengan memanfaatkan potensi lokal menurut Tan (2008) meliputi 5 sintaks yaitu: Meeting the problem, problem annalysis and llearning issues, discovery and reporting, solution presentation and reflection, overview interfration and evaluation. Semua sintaks pada problem based learning dapat melatihkan kemampuan problem solving pada siswa. Sintaks meeting the problem merupakan proses belajar mengidentifikasi phenomena lingkungan untuk merumuskan masalah. Sintaks problem analysis and learning issues memberikan simulasi kepada siswa yang diarahkan untuk menganalisis masalah berdasarkan fenomena yang dihadapinya, mempelajari masalah yang dapat dipelajari. Masalah akan dikerucutkan dari berbagai issue yang ditemukan dan akan membentuk sebuah gambaran besar (Simone, 2008). Gambaran besar masalah dituangkan sebagai rumusan masalah yang dibangun oleh pertanyaan (Chin \& Chia, 2005). Sintaks discovery and reporting merupakan sintaks belajar untuk menemukan dan melaporkan hasil masalah yang telah dipelajari. Hasil masalah yang disusun dapat dijadikan sebagai acuan siswa mencari berbagai macam solusi atas masalah yang diangkat. siswa mencari berbagai alternatif pemecahan masalah, melakukan pengungkapan pendapat, melihat alternatif pemecahan masalah dari berbagai sudut pandang dan akhirnya memilih satu alternatif pemecahan masalah yang paling tepat (Peng, 2004). Sintaks solution presentation and reflection merupakan sintaks kegiatan dimana siswa mempresentasikan solusi dan merefleksi solusi atas masalah yang ditemukan. Solusi yang dipresentasikan merupakan hasil diskusi yang dilakukan siswa dengan kelompoknya. Kemampuan problem solving dapat ditingkatkan melalui adanya diskusi untuk membuat hasil keputusan (Frambach, 2014). Sintaks overview interfration and evaluation merupakan sintaks penarikan kesimpulan serta evaluasi dari solusi yang telah diambil. Siswa merefleksi dampak positif dan negatif dari solusi yang dipilih dan mengidentifikasi perbedaan antara bukti (hasil eksperimen) dan prediksi (hipotesis) 
(Frambach, 2014). Kegiatan merefleksi segala keputusan tidak lepas dari keterampilan siswa dalam memecahkan masalah (Sobel, 2004).

\section{Keterampilan penyelesaian} masalah siswa diukur menggunakan indikator IDEAL yang diperkenalkan oleh Bransford dan Stein (1993) dalam (Brookhart, 2010). Indikator tersebut antara lain meliputi Identify the problem, Define the problem, Examine the options, Act on a plan, Look at the consequences.

Problem based learning menurut Amir (2009) memiliki keunggulan sebagai berikut : Meningkatkan kecakapan pemecahan masalahnya, lebih mudah mengingat, meningkatkan pemahaman, meningkatkan pengetahuan yang relevan dengan dunia praktik, mendorong untuk memaksimalkan kemampuan berfikir. Proses pembelajaran yang mengajak siswa berfikir tingkat tinggi menjadikan siswa berlatih untuk terampil dalam menyelesaikan masalah.

PBL dipadukan dengan potensi lokal yang ada di sekitar sekolah menjadikan pembelajaran lebih kontekstual karena Hasil dari penelitian international di New York USA oleh Eve (2014) menerangkan bahwa siswa akan lebih memahami karakter lingkunganya dengan adanya Place based Education / pendidikan potensi lokal/pendidikan berbasis keunggulan lokal yang diterapkan di sekolah.

\section{Metode Penelitian}

Penelitian adalah Penelitian Tindakan Kelas (PTK) yang bertujuan untuk untuk meningkatkan kemampuan memecahkan masalah (problem solving) melalui penerapan problem based learning pada materi polusi di Kelas X-A SMAN SBBS Tahun Pelajaran 2013/2014.

Prosedur penelitian mengikuti model yang dikembangkan oleh Kemmis dan Robin MC Taggart dalam dalam Arikunto, Suhardjono, dan Supardi (2008) yang berupa model spiral yaitu dalam satu siklus terdiri dari tahap perencanaan, tindakan, observasi dan refleksi. Pelaksanaan tindakan siklus dilaksanakan setelah observasi pra-siklus.

Penerapan tindakan berupa problem based learning dilaksanakan dalam tiga siklus yaitu siklus I, siklus II, dan siklus III. Tahapan dalam tiap siklus meliputi; perencanaan, pelaksanaan, pengamatan dan refleksi. Instrumen yang digunakan dalam penelitian ini berupa performance assesment yang terdiri dari tes kemampuan siswa dalam menyelesaikan masalah (problem solving). Tes problem solving menggunkan indikator IDEAL problem 
solver. Hal ini sejalan dengan penelitian ingin nicapai adalah nilai kemampuan problem solving siswa yaitu 80. PTK dilaksanakan di kelas X-A SMAN SBBS Gemolong dengan jumlah siswa 20 kesemuanya laki-laki. PTK dilaksanakan pada tanggal 6 Mei- 7 Juni 2014.
Bransford (2008). Adapun target yang Hasil dan Pembahasan

Hasil penelitian mengenai kemampuan problem solving ditinjau dari proses dan produk pembelajaran. Berdasarkan IDEAL problem solver uang merupakan rerata dari jumlah skor proses dan produk dari pra-siklus, siklus I, siklus II, dan siklus III disajikan pada Gambar 1.

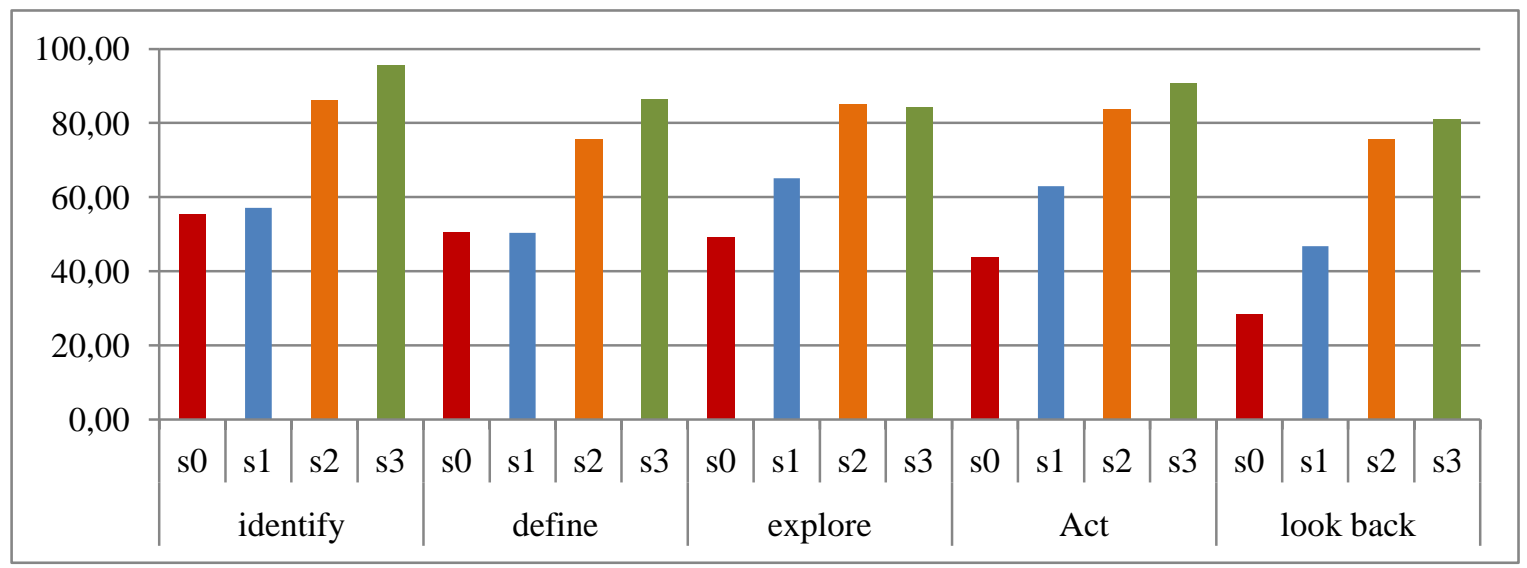

Gambar 1. Diagram Peningkatan kemampuan problem solving Tiap Siklus

Berdasarkan diagram Gambar 1 diketahui bahwa kemampuan problem solving mengalami peningkatan pada setiap siklus. Peningkatanpada indikator Identify dari pra siklus ke siklus 3 yaitu nilai prasiklus 55,38 ke nilai siklus 3 yaitu 95,53. Sintaks meeting the problem pada model pembelajaran PBL memberikan kesempatan kepada siswa untuk mengembangkan kemampuan mengidentifikasi phenomena yang ada di lingkungan sekitar sebagai area lokal yang berpotensi untuk dijadikan media atau sarana pembelajaran. Hal ini sesuai dengan penelitian Christine (2008) yang menyatakan bahwa model pembelajaran PBL efektif untuk meningkatkan kemampuan problem solving dimana salah satu indikator dari kemampuan problem solving adalah siswa mampu mengidentifikasi masalah yang ada di sekitar.

Potensi lokal menjadi salah satu media yang tepat untuk meningkatkan kemampuan siswa dalam mengidentifikasi suatu malah yang ada secara 
kontekstual. Materi pembelajaran yang bersumber dari potensi lokal akan melatih kemampuan siswa dalam mengidentifikasi masalah dan memecahkan masalah yang terkait dengan potensi keunggulan lokal di lingkungan siswa. Upaya melatih kemampuan bersosialisasi dan keterampilan memecahkan masalah sejalan dengan yang dijelaskan oleh David Sobel (2007 dalam H. Pillips dan S. Whately, 2009) bahwa pendidikan berbasis lokal/daerah akan memberikan kesempatan kepada siswa untuk belajar mengidentifikasi masalah dan memecahkan masalah potensi lokal di daerahnya dan merupakan investasi bagi kesejahteraan masyarakat dan aksi sosial. Indikator define and represent the problem mengalami kenaikan dari rerata nilai prasiklus 50,61 ke siklus 3 yaitu 86,29.. Siswa sudah mampu menentukan tujuan yang digunakan untuk mengeksplorasi strategi menyelesaikan masalah. Hal ini seperti yang diungkapkan Bransford (2010) bahwa PBL mampu meningkatkan tujuan dalam suatu kegiatan pembelajaran. Hal ini sejalan dengan pendapat Sobel (2010) yang menyatakan kegiatan siswa merepresentasikan masalah maka siswa mampu mengeksplorasi strategi yang dipilih untuk menyelesaikan masalah. John Dewey (2010) mengungkapkan bahwa siswa sering mengalami kesenjangan antara pengetahuan teori dengan kehidupan yang dijalani, oleh karena itu dalam penelitian Dewey menggunakan kelas sains yang selalu menghubungkan dengan lingkungan sehingga dapat disimpulkan bahwa pendidikan dengan memanfaatkan potensi lingkungan yang ada di sekitar dapat mengatasi masalah kesenjangan di lingkungan.

\section{Indikator eksplore possible} strategies diperoleh bahwa siswa mengalami kenaikan dari rerata nilai prasiklus 49,24 ke siklus 3 yaitu 84,24. Siswa dikatakan mampu mengeklpore strategi yang dipilih untuk memecahkan masalah. Apabila siswa mampu menemukan berbagai cara dan mengambil satu cara yang menurut siswa paling tepat, Menurut Polya (1945) keterampilan problem solving merupakan keterampilan mengambil langkah yang paling tepat dalam menghadapi masalah.

Indikator act on plan mengalami kenaikan dari rerata nilai prasiklus 43,71 ke siklus 3 yaitu 90,76. Sintak overview pada model pembelajaran PBL mampu membuat siswa melihat aksi yang dilakukan dari masalah yang diangkat. Sesuai pernyataan Arends (2008) yang menegaskan bahwa dengan menggunkan PBL siswa dapat melihat dampak negatif dan positif dari strategi yang telah 
digunakan sehingga siswa mampu merefleksi pembelajaran yang telah dilakukan. Hasil penelitian Lynette Zelezny (1999) menemukan bahwa kemampuan siswa dalam memberikan intervensi dalam pembelajaran lebih baik setelah siswa memiliki kebiasaan terhadap lingkungan. Siswa melakukan kegiatan yang diulang dan menjadikan kebiasaan yan ada pada life skill nantinya.

Dalam tiap siklusnya, siswa melakukan kegiatan Act on Plan melalui kelompok belajar siswa dapat berdiskusi dengan siswa yang lainnya untuk menyelesaiakan masalah. Dengan adanya interaksi dan kerjasama dalam kelompok, siswa dapat melakukan penyelesaian masalah dengan baik.

Indikator Look back and Evaluate mengalami kenaikan dari rerata nilai prasiklus 28,23 ke siklus 3 yaitu 80,93. Sesuai dengan sintak terakhir PBL dalam Tan (2004) mampu mengajak siswa untuk meninjau kembali gambaran permasalahan secara keseluruhan dan melakukan evaluasi. Hasil penelitian ini menunujukan PBL dengan memanfaatkan potensi lokal mampu meningkatkan kemapuan siswa dalam menyelesaikan masalah. Indikator look back dapat dilihat dari kecocokan antara tujuan yang ingin dicapai dengan hasil yang didapat. Pada indikator ini, siswa dapat belajar dari strategi yang digunakan untuk menyelesaikan masalah. Upaya melatihkan keterampilan penyelesaian masalah pada siswa SMA, telah membantu siswa dalam meningkatkan kemandirian untuk menghadapai situasi dikehidupan nyata. Hembree (1992) dalam Muijs \& Reynolds (2008) melaporkan bahwa anak-anak yang pernah menerima ajaran tentang keterampilan penyelesaian masalah menunjukkan kinerja yang lebih baik secara signifikan dibanding mereka yang belum pernah menerimanya. Selain itu, jika kemampuan penyelesaian masalah telah diperoleh, seseorang tidak sekedar dapat menyelesaikan masalah serupa tetapi diharapkan dapat menyelesaikan masalah yang berbeda dalam kehidupan sehari-hari (Gagne, 1985). Penerapan model Problem Based Learning (PBL) dalam melatih keterampilan penyelesaian masalah siswa telah berhasil melatihkan keterampilan penyelesaian masalah siswa yang didasarkan pada indikator keterampilan penyelesaian masalah IDEAL. Hal ini sejalan dengan pendapat Nur (2011) yang menyatakan bahwa, model pembelajaran berdasarkan masalah tidak dirancang untuk membantu guru menyampaikan sejumlah informasi kepada siswa, melainkan untuk membantu siswa mengembangkan keterampilan berpikir, penyelesaian masalah dan intelektual, 
belajar peran orang dewasa yang autentik, dan menjadi pebelajar mandiri. Hasil peningkatan keterampilan penyelesaian masalah ini juga sesuai dengan hasil penelitian terdahulu yang dilakukan oleh Novianti (2012). Di dalam penelitiannya, dikatahui bahwa keterampilan penyelesaian masalah dan penguasaan konsep siswa meningkat secara signifikan setelah diterapkannya model PBL dalam pembelajaran. Dalam penelitian tersebut disebutkan pula bahwa dalam implementasi pembelajaran Biologi dengan menggunakan model PBL perlu diperkuat dengan penugasan yang menghadapkan siswa pada situasi baru, baik di dalam maupun di luar jam pelajaran. Oleh karena itu, penerapan PBL dalam pembelajaran tidak cukup hanya beberapa kali pertemuan sehingga dengan demikian diharapkan akan berdampak lebih baik pada peningkatan kemampuan penyelesaian masalah siswa. Hal serupa juga diungkapkan oleh Wiyanti (2012) yang menyatakan bahwa penerapan pembelajaran berdasar masalah dapat melatih keterampilan berpikir siswa berdasarkan solo taksonomi. Upaya melatihkan keterampilan berpikir akan berdampak pula pada keterampilan penyelesaian masalah. Penyelesaian masalah merupakan salah satu keterampilan berpikir tingkat tinggi. Menurut Nur (2011), berpikir merupakan kemampuan menganalisis, mengkritisi, dan merumuskan simpulan berdasarkan inferensi dan pertimbangan yang seksama.

Keunggulan potensi lokal dalam membantu siswa dalam meningkatkan proses dan hasil belajar ditinjau dari aspek problem solving dibuktikan melalui terlaksananya sintak-sintaks pada setiap siklus. Menurut Dhany (2011) dalam tiap siklus terdapat indikator berupa IDEAL yang digunakan untuk menilai proses dan hasil dari pembelajaran. PBL dengan memanfaatkan Potensi lokal menjadi sangat berpengaruh terhadap kemampuan siswa dalam meningkatkan kemampuan tingkat tinggi siswa khususnya dalam aspek problem solving.

\section{Kesimpulan}

Kesimpulan penelitian adalah penerapan problem based learning dengan memanfaatkan potensi lokal dapat meningkatkan kemampuan problem solving pada materi polusi di kelas X-A SMAN SBBS Tahun Pelajaran 2013/2014.

\section{Daftar Pustaka}

Amir, M. (2009). Inovasi Pendidikan Melalui Problem Based Learning. Jakarta: Kencana Prenda Media Group Arends, R. I. (2008). Learning to Teach. New York: McGraw Hill Companies, Inc 
Brookhart, S. M. (2010). How to Assess Higher-Order Thinking Skills in Your Classroom. Virginia USA: ASCD Resourches

Bransford, J.D. dan Stein B.S. (1993). The Ideal Problem Solver: A Guide for Improving Thinking, Learning, and Creativity. Second Edition. New York: W. H. Freeman \& Company

C. Preston (2003). Grounding Knowledge: Environmental Philosophy, Epistemology, and Place. Athens, GA: University of Georgia Press

Dewey, J. (1997). Experience and education. New York, NY: Touchstone

Dhany, I.N. (2011). Pengembangan Perangkat Pembelajaran Model IDEAL Problem Solving Materi Dimensi Tiga

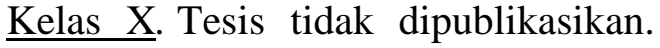
Semarang: PPs UNNES

D. Lloyd, 'Sojourning in the Art World: Service-Learning in Philosophy of Art', in Beyond the Tower, p. 202

D. Orr (1994). Earth in Mind: On Education, Environment, and the Human Prospect. Albany: State University of New York Press

Eve T,. Kenzie, M. M., Coy, K. M. (2014). Land education: Indigenous, postcolonial,and decolonizing perspectives on place and environmental education research. Informa Ltd Registered in England and Wales: Routledge

Janneke, F. M.. 2014. The Cultural Complexity of Problem Based Learning accross the World. Interuniversity Centre for Educational Research. Maastricht University

Gruenewald, D., \& Smith, G. (Eds.). (2008). Place-based education in the global age: Local diversity. New York, NY: Lawrence Erlbaum Associates

G. Smith (2002). 'Place-Based Education: Learning To Be Where We Are'. Phi Delta Kappan http://www.theguardian.com/news/dat ablog/2013/dec/03/pisa-results- country-best-reading-maths-science [08/01/2014]

King, P. F., Goodson, M. L., \& Rohani, F. (2010). Higer order thinking skills. cala.fsu.edu

Nur, M. (2011). Model Pembelajaran Berdasarkan Masalah. Surabaya: Pusat Sains dan Matematika Sekolah

OECD. (2010). Problem Solving Frame Work. Paris: OECD

Polya, G. (19450). How to Solve it.Pricenton. NJ: Pricenton University Press

Resnick, L. B. (1987). Education And learning ro Think. Washington D.C: National Academy Press

Slavin, R. (2009). Cooperative Learning. Bandung: Nusa Media

Tan, O. S. (2004). Enhanching Thinking through Problem Based learning Approaches. Singapura: Cengage Learning

Peng, C.N. (2004). Successful ProblemBased Learning for Primary and Secondary Classrooms. Singapore: Federal Publications

Simone, C. D. (2008). Problem-Based Learning: a framework for prospective teachers' pedagogical problem solving. University of Ottawa, Ontario, Canada: Rouledge Group

Smith, G. A., \& Sobel, D. (Eds). (2010). Place and community based education in schools. New York, NY: Routledge

Sobel, D. (2004). Place-based education: Connecting classrooms and communities. Great Barrington, MA: The Orion Society

Wiyanti. (2013). Penerapan Problem Based Instruction (PBI) Pada Materi Bahan Tambahan Pangan untuk Melatih Keterampilan Berpikir Berdasarkan SOLO Taksonomi Siswa Kelas VIII SMP. Skripsi Tidak dipublikasikan. Surabaya

Wena, Made. (2009). Strategi Pembelajaran Inovatif Kontemporer. Jakarta: Bumi Aksara 